\title{
RELEVAMT IDEALISM
}

New York, N.Y. Sir: During the past few months Worldview has initiated a valuable discussion of the relationship between ethics and world affairs. This communication is an attempt to continue tho discussion in an area where, it seems to me, a great deal of reexamination is needed if we are to discover a policy that is both morally and politically responsible.

In the current debate over our nuclear weapons policy, for example; we hear the volces of two extremes, neither of which offers a very hopeful course of action. One extreme is the security-conscious militant who looks at every issue in terms of the military strength of the United States vis-a-vis "the enemy," and can never escape from the frozen logic of the Cold War. The opposite extreme is represented by the traditional pacifist viewpoint which can see nothing but evil in any defense effort, and favors not only test suspension but the unilateral abandonment of all nuclear and conventional weapons.

Neither of these views has much to offer the American people, or the religious conscience, as a policy productive of peace. The militant overlooks the overwhelming psychological and moral problems that an unrestrained atomic arms race creates, while the pacifist embraces an escapist solution to the complex problems of the power struggle. Unfortunately, much of the debate on this issue is left to the protagonists of these two views. We continue to lack a creative alternative that transcends them both.

One group which has attempted to find a way between these two extremes is the "realist." But while the realists have made an important criticism of the inadequacies of utopian liberalism they have failed to produce any real alternative policies, and the effect of their criticism has increasingly been to strengthen the position of the Pentagon militants.

The realists have reacted against the exaggerated idealism of earlier liberal thought. They consider the abortive inter-war attempts at disarmament and arbitration of disputes among nations as outstanding examples of the danger of wishful thinking in world politics, and they are skeptical about many recent attempts to deal with the problem of peace through the United Nations and other international organizations. Peace, they insist, will be the product of strong democratic powers ready to defend their interests in a world threatened first by Fascist aggression and now by Communist imperialism.

"Realist" thinking has helped us to understand the various ambiguities and difficulties that must be confronted if we are ever to build a peaceful world, but recently a "conservative realism" has crystallized and has become little better than a sophisticated defense of the status quo.

One of the most devastating effects of this "conservative realism" has been its weakening of the moral ground on which many liberal proposals stand. It has introduced a compromising ethic which rea. ognizes as valid almost no other moral criterion than the "national interest." Realists are in danger of substituting a kind of national or tribal morality for the utopian morality of liberal idealism.

Therefore, while retaining the realist's insights on the fallacies of liberal utopianism, I think we would do well to reconsider the implications of the moral law for national policies. Out of fear of the vagaries of "the social gospel" we have strayed far from the very concept of moral law. And moral law has bocome assoctated in the minds of many with Natural Law," and is therefore dismissed as something ab. stract, or automatic. But the moral law is something quite different from what is commonly considered "Natural Law." The moral law does not tyrannically dictate abstract rules for society, but rather invites men's allegiance to moral standards.

The moral law represents the Will of God concerning the just relationships that ought to exist among men. Its existence is not rendered any the less valid because of man's refusal to recognize its claims upon him and his failure to apply it in his daily existence. In a timeless manner the Kingdom of God grows as men come to recognizo and apply the moral law to their personal and institutional relationships. Although we continuously fail to respond in our personal lives and our social forms to the supreme law of the Divine Will for us, yet there are times and places when we achieve what Reinhold Niebuhr has called a "proximation" of the moral law," and thus approach the gates of the Kingdom. As John Bennett expressed it in What the Christian Hopes for in Society: "Within human history we may not see the kingdoms of this world become the Kingdom of Cod, but we may see among them in many places and at many times communities, institutions, and corporate acts of justice which truly embody the grace and power of that Kingdom."

It is painfully obvious that we never completely fulfill the moral law either individually or colleo. tively, and life is a continuous process of striving to overcome our sinfulness and more closely proxi- 
mate this structure of the Will of God for man. No particular policy of a government can be said to be fully predicated upon the moral law. Indeed, it is often difficult in the light of cultural and economic differences of peoples to read the moral law unambiguously. Yet despite ambiguities and conflicts of principle, nations and peoples do stand under the obligation to seek and approximate the moral law in . their policies and actions.

The grave weakness of many pacifist and idealistically "liberal" solutions has been their claim that national policies must be patterned upon the absolute demands of the moral law. They assume too easily that the moral law is perfectly perceivable and immediately applicable in every situation, if only men have good will. But, at the same time, the fallacy of "conservative realism" is its tendency-in practice at least-to deny the valid claims of morality upon the political order. The consequence of this tendency has been the despairing substitution of "national interest" for the moral law as the norm for judging foreign policy.

What we need is a realistic idealism-one that combines a full acceptance of the moral law's relevance with an understanding of the limitations that politics places upon the application of moral imperatives. Although this would be idealism in the sense of surrender to ethical ideals which transcend self and nation, it would also be rigorous realism in its knowledge of the limitations existing in a world where even moralists must seek justice through political action.
For some social issues, the relevance of the moral law is more obvious than for others. Despite the many failures and disappointments of the last fifty years, for example, the struggle to transcend the insecurity of the nation-state remains one such social issue directly related to moral demands. While not all that the United Nations does strengthens peace or approximates the moral law, much of its activity has done so, and many specific actions it might take would immeasurably advance these ultimate ends. Take, for example, the prospects in the field of atomic weapons control.

Negotiations between the Soviet Union and Western powers have begun on the technical aspects of establishing an international control system or the elimination of nuclear testing. It is to be expected that any such control system will operate under the auspices of the United Nations. In the establishment of such a system lies a means of transcending the hopelessness of the extremes propounded by the nationalist militants and the utopian pacifists. Such an agreement will not offer full security to the big powers, nor will it enable us to abandon national defense systems. But it will create a new atmosphere in which disarmament negotiations can be conducted. And it will revive the hopes of all peoples that, through the United Nations, they can achieve a gradual expansion of security and welfare-one which some day may offer a real alternative to the insecurity of international anarchy and nuclear war.

GEORGE W. SHEPHERD, JR.

worldview

SUBSCRIPTION BLANK

170 East 64th Street

New York 21, N. Y.

Please enter my subscription to worldview

Check enclosed \$.

Name

Please bill

Address

One Year $\$ 2.00$

(Make checks payable to worldview) 